\title{
Ontogenetic variation in habitat association for four groundfish species in the Gulf of Maine - Georges Bank region
}

\author{
Elizabeth T. Methratta ${ }^{1,2, *}$, Jason S. Link ${ }^{1}$ \\ ${ }^{1}$ National Marine Fisheries Service, Northeast Fisheries Science Center, Food Web Dynamics Program, 166 Water Street, \\ Woods Hole, Massachusetts 02543, USA \\ ${ }^{2}$ Present address: Department of Biology, University of Pennsylvania, Philadelphia, Pennsylvania 19104, USA
}

\begin{abstract}
We explored how size class distributions for 4 important groundfish species, Atlantic cod Gadus morhua, haddock Melanogrammus aeglefinus, spiny dogfish Squalus acanthias and silver hake Merluccius bilinearis, are related to depth, temperature, substrate and time-block for the fall and spring of a $35 \mathrm{yr}$ time period in the Gulf of Maine - Georges Bank region. We examined the relative importance of each factor and how relative importance changes with season. Size increased with depth during both seasons for G. morhua and for $M$. aeglefinus during the fall, but decreased with depth for $M$. aeglefinus during the spring. Haddock size class distributions in the spring were also related to bottom temperature, with smaller individuals generally occurring in the warmest waters. For $S$. acanthias, depth was also the primary environmental variable explaining size class distributions in the fall, although size decreased with depth for this species. In the spring, bottom temperature was more important for spiny dogfish with smaller individuals associated with warmer bottom waters. Similarly, bottom temperature had the most explanatory value for $M$. bilinearis during both seasons, with size increasing with temperature. Seasonal associations with depth and temperature are related to spawning migrations, thermal preferences and other ecological factors. Timeblock accounted for a notable amount of variance, particularly for $S$. acanthias and $M$. bilinearis, and was reflective of how population size structure has responded to exploitation over the time series. The local-scale relationships between abundance and substrate previously established for some species were not strong at the broader spatial scale we examined. Understanding how habitat associations change with ontogeny will aid in refining spatial fisheries management approaches and in delineating essential fish habitat.
\end{abstract}

KEY WORDS: Life history · Spatial distribution · Northwest Atlantic $\cdot$ Fisheries · Environmental gradient

\section{INTRODUCTION}

Ontogenetic shifts in habitat use are evident for many fish species (Werner \& Gilliam 1984). These shifts reflect changes in morphology, physiology and ecological function that occur throughout life history (e.g. Fry 1971, Werner \& Gilliam 1984, Swain 1993). Many established fish-habitat relationships are based on juvenile life stages because these stages are particularly vulnerable to predation (e.g. Lindholm et al.
1999). This previous work has necessarily targeted shallow regions that provide important nursery habitat for many groundfish species. However, the distribution of many groundfish extends out into deeper portions of the continental shelf and covers a broad range of environmental gradients.

Environmental gradients in depth, temperature and substrate type are related to numerous factors that can influence ontogenetic changes in fish-habitat associations. Temperature is related to rates of physiological 
processes (e.g. Fry 1971) and for many species the tolerable thermal range is well known (e.g. Collette \& Klein-MacPhee 2002). Depth associations may be related to such factors as distribution of prey, migratory patterns, reproductive life history strategies and sediment type (e.g. Collette \& Klein-MacPhee 2002). Depth associations of thermally sensitive species may shift on a seasonal basis (e.g. Murawski \& Finn 1988) because bottom temperature varies with both bottom depth and season on the northeast US Continental Shelf (Drinkwater \& Mountain 1997), A third aspect of habitat, benthic substrate type, influences survivorship through mediation of predator-prey interactions (e.g. Lindholm et al. 1999).

Although much work has explored multi-species assemblage associations with environmental gradients at broad spatial scales (e.g. Overholtz \& Tyler 1985, Murawski \& Finn 1988, Garrison 2000) less effort has focused on size class distributions within species along similar gradients at comparable scales. However, local-scale patterns suggest that the association of particular size classes with certain aspects of habitat may influence broad-scale population distributions. For example, particular size classes of some species are associated with colder temperatures (e.g. McCauley \& Read 1973), deeper depths (e.g. Linehan et al. 2001) and coarser substrates (e.g. Lindholm et al. 1999) at relatively local scales, i.e. within a bay, coastal zone or portion of the shelf. These relationships have the potential to influence the abundance and distribution of populations at broad spatial scales.

In the Georges Bank - Gulf of Maine region, fishing pressure has directly affected population size of targeted groundfish species (Link \& Brodziak 2002). As fisheries management continues to explore spatial management options, it will become increasingly important to evaluate concurrently the multiple factors that delineate fish habitat (Fluharty 1999). This requires a detailed understanding of how species size classes are distributed along environmental gradients. Our goal was to examine how the distribution of size classes for 4 groundfish species is associated with gradients in bottom depth, bottom temperature, substrate type and time-block.

\section{MATERIALS AND METHODS}

The abundances of Atlantic cod Gadus morhua, haddock Melanogrammus aeglefinus, spiny dogfish Squalus acanthias and silver hake Merluccius bilinearis was obtained from a 35 yr time series of bottom trawl surveys carried out by the Northeast Fishery Science Center (NEFSC). The bottom trawl surveys collect data from 350 to 400 sampling stations, approximately 1 per 200 square nautical miles, from Nova Scotia to Cape Hatteras using a stratified random sampling design (Azarovitz 1981). Sampling stations within strata were sampled using a No. 36 Yankee or comparable bottom trawl deployed for 30 min at a tow speed of $6.5 \mathrm{~km} \mathrm{~h}^{-1}$. Several parameters including abundance and individual size are recorded for all species. A more detailed description of the bottom trawl sampling design and methodology has been published elsewhere (Azarovitz 1981). We examined data from the fall and spring for 3 nearly decadal time-blocks (1968-1979, 1980-1989, 1990-2002). Species were binned into individual size classes ( 5 or $10 \mathrm{~cm}$ intervals) because size is often used as a proxy for ontogenetic stage (Table 1).

We evaluated bottom depth, bottom temperature and substrate grain size as explanatory environmental variables in the analysis. Bottom depth and bottom temperature data were recorded for each tow of the NEFSC bottom trawl surveys. The substrate data set used was based on a surficial sediment database for this region that was assembled by the US Geological Survey (Poppe et al. 2003). This data set is a compilation of numerous surveys carried out by multiple investigators that primarily employed grab samplers to collect surficial sediment samples. The spatial extent of the substrate data overlapped with that of the bottom trawl surveys in the Gulf of Maine, on Georges Bank and in parts of Southern New England, so we focused our analyses primarily on these regions.

To examine relationships between fish abundance and environmental variables in a spatially explicit manner, a grid composed of spatial cells measuring $10 \mathrm{~min}$ of latitude by $10 \mathrm{~min}$ of longitude $\left(185.2 \mathrm{~km}^{2}\right.$ per cell) was overlaid on the region. The number of spatial cells in the analysis ranged from 705 to 746 (median = 719.5) depending on the season and time-block. Each

Table 1. Size class information for species analysed

\begin{tabular}{|c|c|c|c|c|c|c|c|c|}
\hline \multirow{2}{*}{ Common name } & \multirow{2}{*}{ Scientific name } & \multirow{2}{*}{$\begin{array}{l}\text { Individuals } \\
\text { sampled }\end{array}$} & \multirow{2}{*}{$\begin{array}{c}\text { Size } \\
\text { interval }(\mathrm{cm})\end{array}$} & \multicolumn{4}{|c|}{ Size categories $(\mathrm{cm})$} & \multirow{2}{*}{$\begin{array}{l}\text { Size range } \\
(\min / \max )\end{array}$} \\
\hline & & & & $\mathrm{S}$ & $\mathrm{M}$ & $\mathrm{L}$ & $\mathrm{XL}$ & \\
\hline Atlantic cod & Gadus morhua & 44324 & 10 & $1-20$ & $21-50$ & $51-80$ & $>80$ & $2 / 150$ \\
\hline Haddock & Melanogrammus aeglefinus & 48660 & 10 & $1-20$ & $21-50$ & $>50$ & & $3 / 104$ \\
\hline Spiny dogfish & Squalus acanthias & 147672 & 10 & $1-40$ & $41-60$ & $61-80$ & $>80$ & $12 / 122$ \\
\hline Silver hake & Merluccius bilinearis & 179293 & 5 & $1-20$ & $21-40$ & $>40$ & & $2 / 78$ \\
\hline
\end{tabular}


sampling station (i.e. tow) was assigned to the spatial cell in which it occurred and the average of each biological and environmental variable was calculated for each spatial cell. Data for individual species were summed across stations within a spatial cell. The mean biomass per tow within a spatial cell was determined for each species by dividing that sum by the number of stations in the spatial cell. The average depth, temper- ature and grain size were calculated in a similar manner (Figs. $1 \& 2$ ). There were approximately $3.1 \pm 0.03$ (mean $\pm \mathrm{SE}$ ) stations per spatial cell on average (range: 1 to 18) for each season and time-block combination. There was an average of $2238 \pm 0.03$ stations sampled overall for each season and time-block combination. If spatial cells contained no tows they were not included in the analysis.
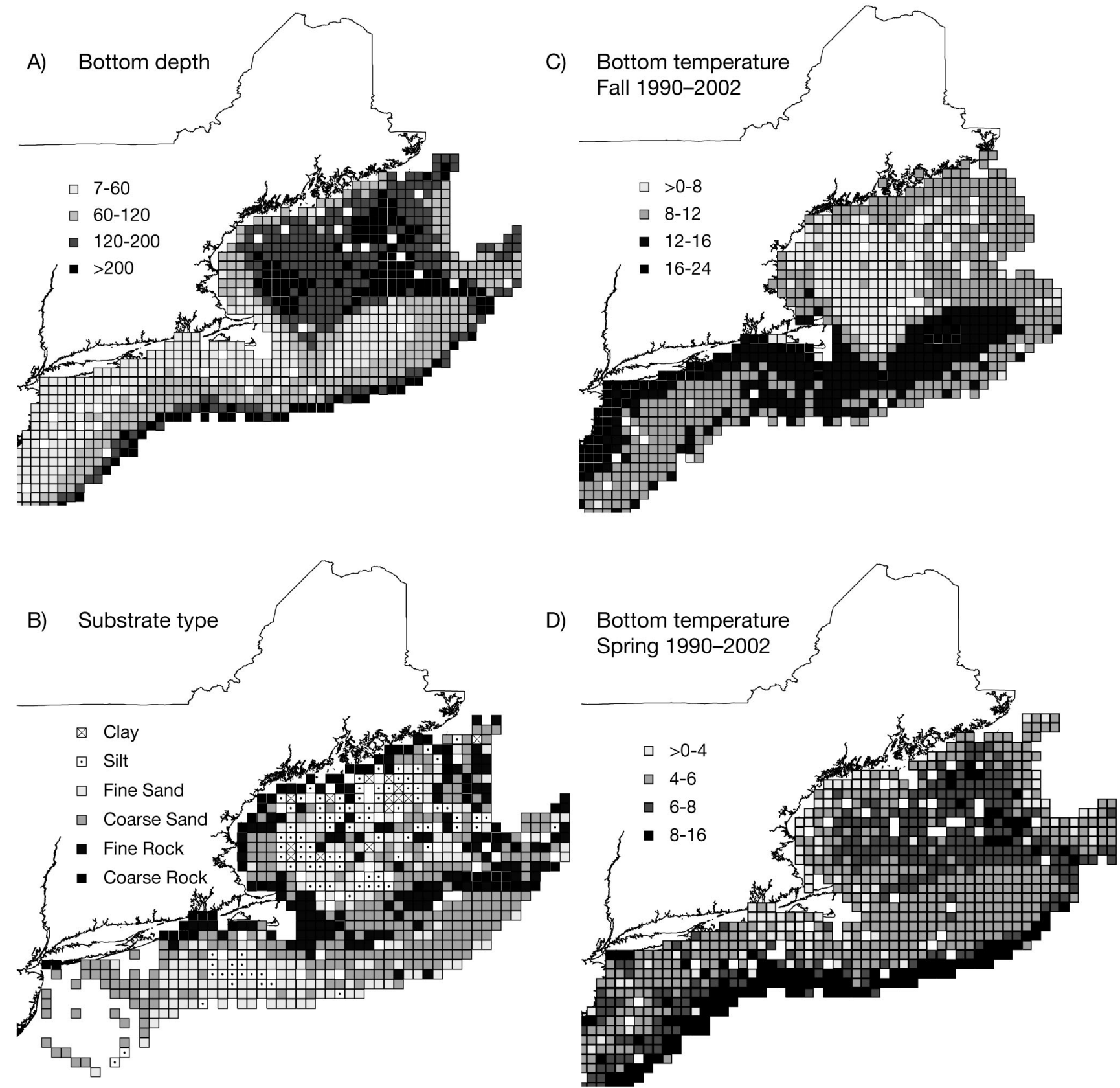

Fig. 1. (A) Average bottom depth (m); (B) substrate type based on average grain size (mm); categories based on the Wentworth (1922) scale in Gulf of Maine - Georges Bank region; $(\mathrm{C})$ average bottom temperature $\left({ }^{\circ} \mathrm{C}\right)$ during fall for an example time-block (1990-2002); (D) average bottom temperature $\left({ }^{\circ} \mathrm{C}\right)$ during spring 1990-2002 

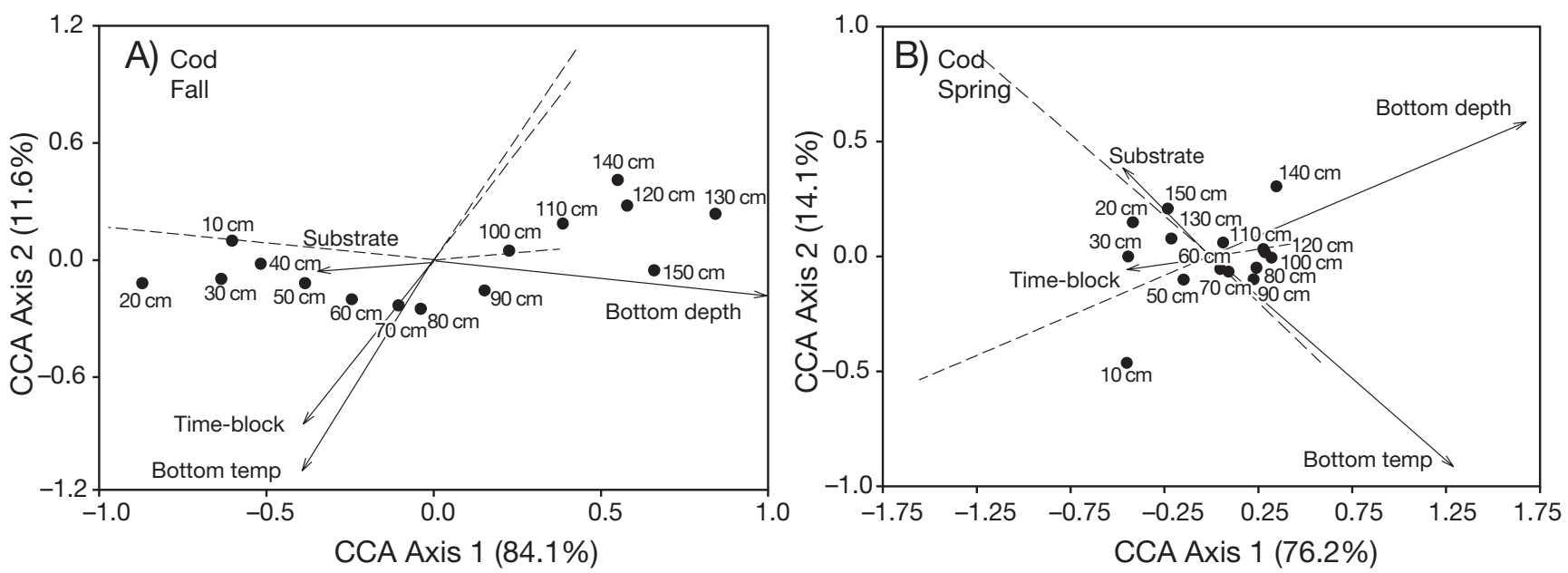

Fig. 2. Gadus morhua. Canonical correspondence analysis (CCA) ordinations for Atlantic cod size classes during (A) fall and (B) spring. First axis was significant during both seasons (fall, $F=44.011, \mathrm{p}<0.01$; spring, $F=39.391, \mathrm{p}<0.01$ ). Depth was most closely associated with CCA Axis 1 in fall whereas both depth and temperature contributed to CCA Axis 1 in spring. Size class labels represent maximum length in each $10 \mathrm{~cm}$ size class

We employed canonical correspondence analysis $\left(\mathrm{CCA}_{i}\right.$ ter Braak 1986) to examine the relationship of size classes with bottom depth, bottom temperature, substrate grain size and time-block. An individual CCA was carried out for each species and season using square-root transformed data. CCA is a commonly used method of direct gradient analysis (Birks et al. 1996) that places subjects (i.e. size classes) along explanatory gradients such that subjects that are relatively more abundant under a particular set of explanatory conditions are grouped together. To do this, CCA determines a score for each subject which is constrained to linear combinations of the explanatory factors in the analysis. The scores are presented in a biplot depicting the subject scores as points and the explanatory factors as vectors. The length of each vector on the biplot indicates the magnitude of its relative importance in the ordination. The position and direction of each vector indicates how it is correlated with the other vectors and with each axis. The relative position of subjects along the vectors reflects how subjects are associated with each factor relative to the other subjects in the ordination. Significance of the canonical axis accounting for the most variance was determined using Monte Carlo permutation methods (ter Braak 1986). The large number of spatial cells (705-746) which each contained independent sampling stations provided a sufficient number of degrees of freedom for our analyses.

CCA also determines the total amount of inertia or variance accounted for by the set of explanatory factors. We used partial ordination techniques to determine the percentage of variance attributable to each factor in the CCAs (ter Braak 1986). We note that because data are aggregated to 10 min spatial cells, the variance attributable to within-cell variation is not captured by the analyses. Analyses were carried out using the CANOCO software package (ter Braak 1986). An advantage of CCA over other methods is that it allows the simultaneous exploration of multiple environmental factors and multiple size classes. For this reason, CCA is a powerful data exploration tool and we used it in this sense.

\section{RESULTS}

\section{Atlantic cod Gadus morhua}

Depth had the most explanatory value in both fall and spring, with size increasing with depth, reflecting ontogenetic movements into deeper water during both seasons. This pattern is substantiated by visual inspection of the spatial distributions of cod size classes. In the fall, large to extra-large cod (Table 1) were more prevalent than smaller cod in deeper water of the Gulf of Maine, whereas small to medium cod were more abundant in the shallow water of Georges Bank and coastal New England (Figs. 2A \& 3A,B). The range of depths occupied by cod was narrower in the spring compared to fall because of the greater number of larger cod in shallower spawning sites, namely Georges Bank and coastal New England (Figs. 2 \& 3). Temperature was also important in the spring. Cod that were in the 1-10 $\mathrm{cm}$ size class were associated with warmer portions of the region whereas other, larger size classes were most abundant in relatively cooler portions of the region (Fig. 2B). 


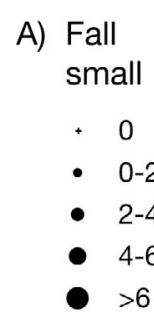

C) Fall

medium

- 0

- $>0-5$

- 5-10

- 10-15

- >15

E) Fall large

. 0

- $>0-5$

- 5-10

- >15
- 10-15
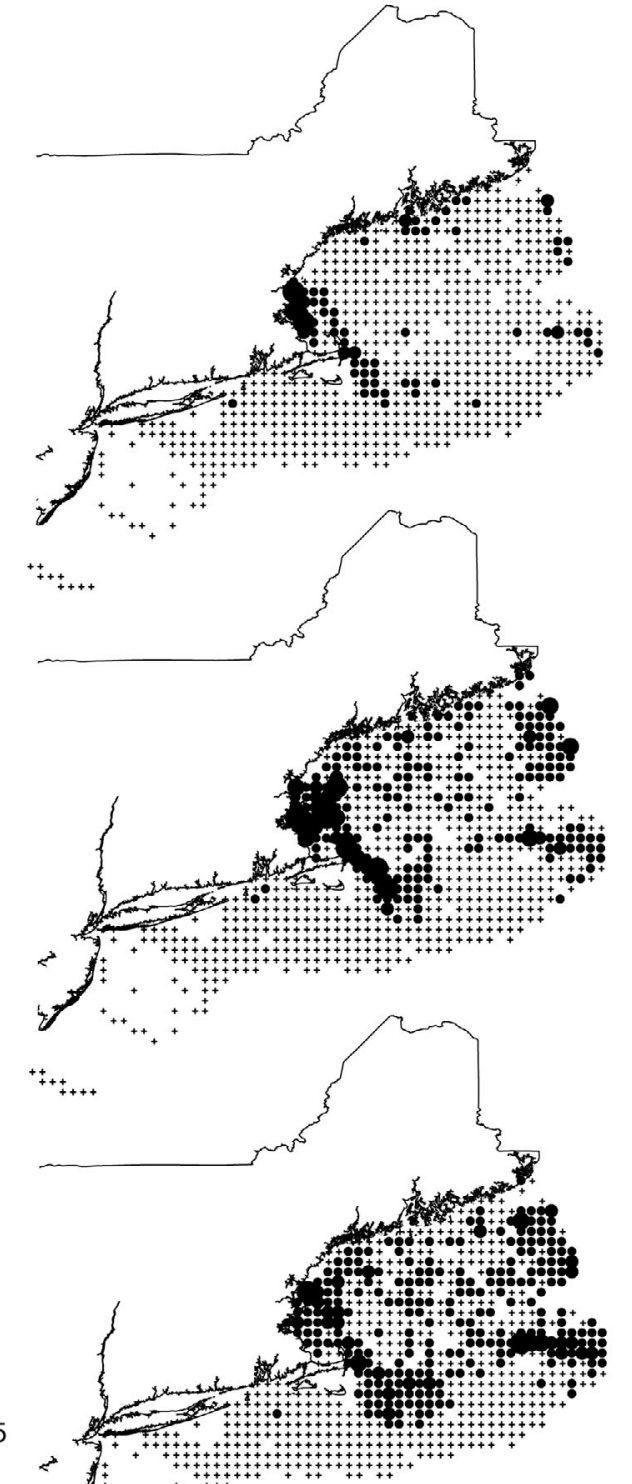

G) Fall extra large
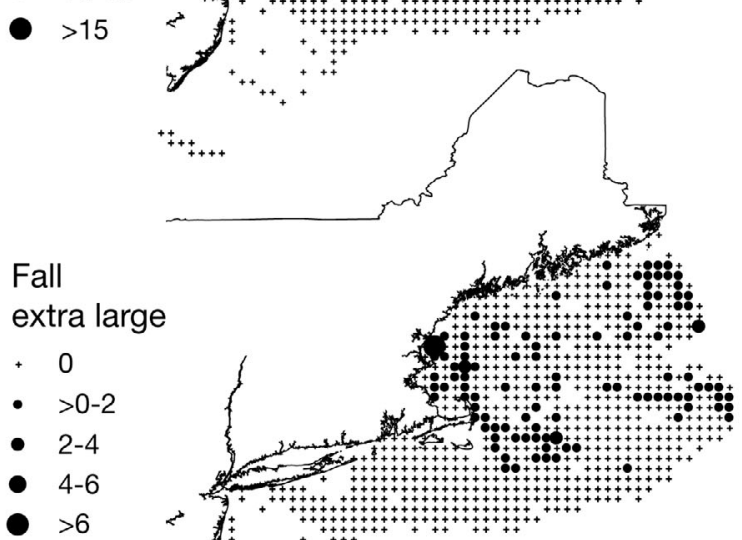

B) Spring small

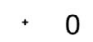

- $>0-2$

- 2-4

- 4-6

- >6

D) Spring medium

$+0$

- >0-5

- $5-10$

- 10-15

- >15
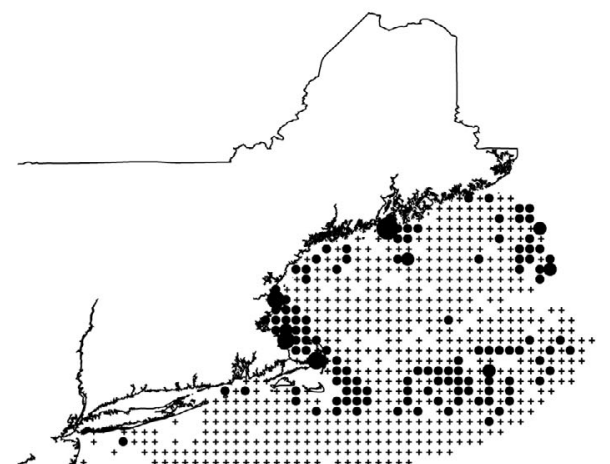

F) Spring large

$+0$

- >0-5

- $5-10$

- 10-15

- >15
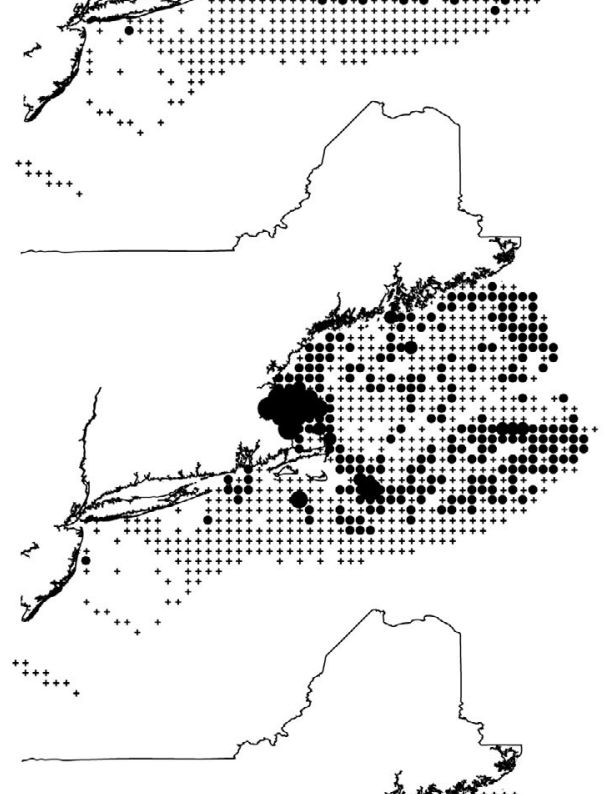

H) Spring extra large

- 0

- >0-2

- 2-4

- 4-6

$>6$
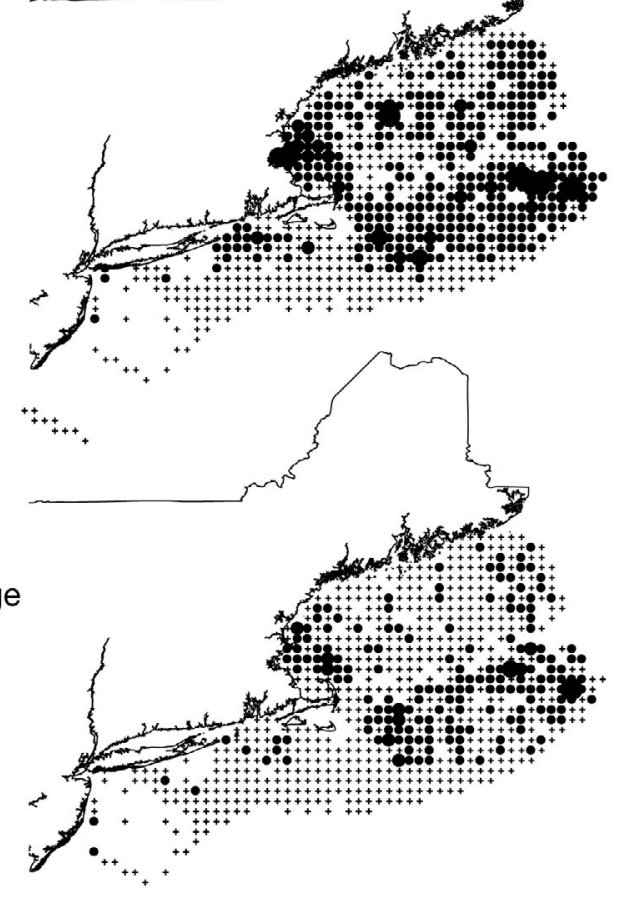

$*++$,

Fig. 3. Gadus morhua. Spatial distribution of $(\mathrm{A}, \mathrm{B})$ small $(\mathrm{C}, \mathrm{D})$ medium $(\mathrm{E}, \mathrm{F})$ large and $(\mathrm{G}, \mathrm{H})$ extra-large cod in Gulf of Maine Georges Bank region for fall and spring for an example time-block (1990-2002) 
Although depth accounted for most of the variance in both fall and spring, the relative ranking of explanatory factors varied between seasons (Table 2). Timeblock ranked second in the fall whereas bottom temperature ranked second during the spring, accounting for more than twice as much variance as it did in the fall. Reduced abundance of large size classes of cod due to exploitation over the decadal time-blocks likely explains the fall time-block effect. Bottom temperature was relatively more important in the spring. Bottom temperature in the fall and substrate type in both seasons each accounted for comparatively little variance. However, smaller size classes were generally associated with coarser bottom types at least in the fall (Figs. $2 \& 3$ ). The total variance accounted for was also

Table 2 . Total variance accounted for by all variables together and $\%$ total variance attributable to each individual variable. Bold: largest value from each analysis

\begin{tabular}{|lrrrrr|}
\hline $\begin{array}{l}\text { Species } \\
\text { Season }\end{array}$ & $\begin{array}{c}\text { Total } \\
\text { variance }\end{array}$ & $\begin{array}{c}\text { Depth } \\
(\mathrm{m})\end{array}$ & $\begin{array}{c}\text { Bottom } \\
\text { temp. }\left({ }^{\circ} \mathrm{C}\right)\end{array}$ & $\begin{array}{c}\text { Substrate } \\
\text { block }\end{array}$ \\
\hline $\begin{array}{l}\text { Atlantic cod } \\
\text { Fall }\end{array}$ & & & & & \\
$\quad$ Spring & 3.71 & $\mathbf{2 . 7 4}$ & 0.46 & 0.21 & 0.67 \\
Haddock & & $\mathbf{1 . 4 5}$ & 0.75 & 0.19 & 0.47 \\
$\quad$ Fall & 16.52 & $\mathbf{9 . 3 8}$ & 1.22 & 0.45 & 0.84 \\
$\quad \begin{array}{l}\text { Spring } \\
\text { Spiny dogfish }\end{array}$ & 3.73 & 1.39 & $\mathbf{1 . 5 4}$ & 0.29 & 0.51 \\
$\quad$ Fall & 6.97 & 1.97 & 1.07 & 1.19 & $\mathbf{2 . 1 4}$ \\
$\quad \begin{array}{l}\text { Spring } \\
\text { Silver hake }\end{array}$ & 15.38 & 1.16 & $\mathbf{1 0 . 3 4}$ & 0.25 & 2.73 \\
$\quad$ Fall & 15.13 & 2.54 & 2.62 & 1.44 & $\mathbf{3 . 2 1}$ \\
$\quad$ Spring & 12.15 & 2.46 & $\mathbf{5 . 8 0}$ & 0.14 & 2.59 \\
\hline
\end{tabular}

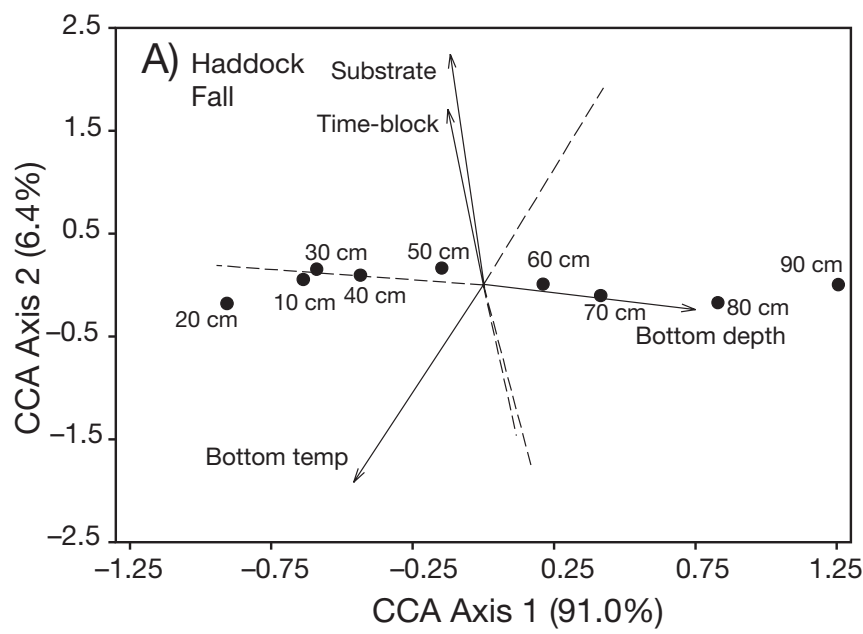

lower for cod compared to the other species in the current study (Table 2).

\section{Haddock Melanogrammus aeglefinus}

Size primarily increased with depth during the fall but decreased with depth during the spring (Fig. 4). However, the $21-30 \mathrm{~cm}$ size class remained in relatively shallow habitat during both seasons. Bottom temperature was the most important factor in the spring, with fish size generally decreasing with increasing temperature. The exception to this pattern was the settlement size class $(1-10 \mathrm{~cm})$, which associated with the coolest bottom temperatures (Fig. 4).

These environmental relationships are consistent with the seasonal spatial distributions for haddock. Similar to cod in the fall, smaller haddock were more prevalent in the shallow water of Georges Bank and coastal New England in both seasons (Fig. 5A,B). Medium haddock abundance was high in the deeper northeastern portions of Georges Bank as well as in the Gulf of Maine, while large haddock were most common in the deeper waters of the Gulf of Maine in the fall (Fig. 5C,E). During the spring, most size classes were abundant in the shallower portions of Georges Bank (Fig. 5). Thus, as with cod, the distribution of larger individuals overlaps more with small individuals during the spring (Figs. 4B \& 5), reducing the explanatory power of depth in the spring compared to fall. Instead, the distribution of haddock is more related to temperature in the spring (Table 2).

Although substrate explained only a small proportion of variance (Table 2), smaller fish were generally

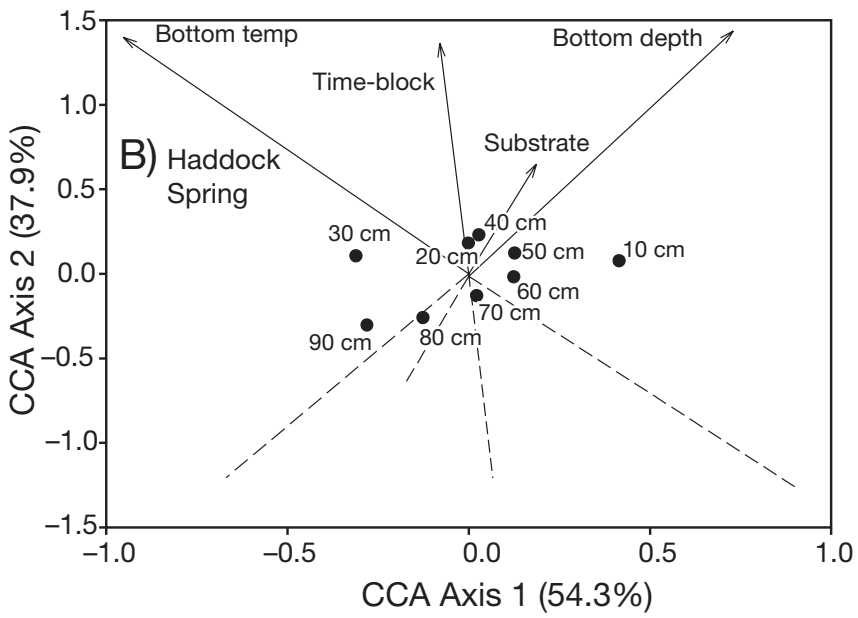

Fig. 4. Melanogrammus aeglefinus. CCA ordinations for haddock size classes during (A) fall and (B) spring. First axis was significant during both seasons (fall, $F=208.919, \mathrm{p}<0.01$; spring, $F=20.022, \mathrm{p}<0.01$ ). Depth was most closely associated with CCA Axis 1 in fall, whereas temperature was the most important component of this axis in spring. Size class labels represent maximum length in each $10 \mathrm{~cm}$ size class 

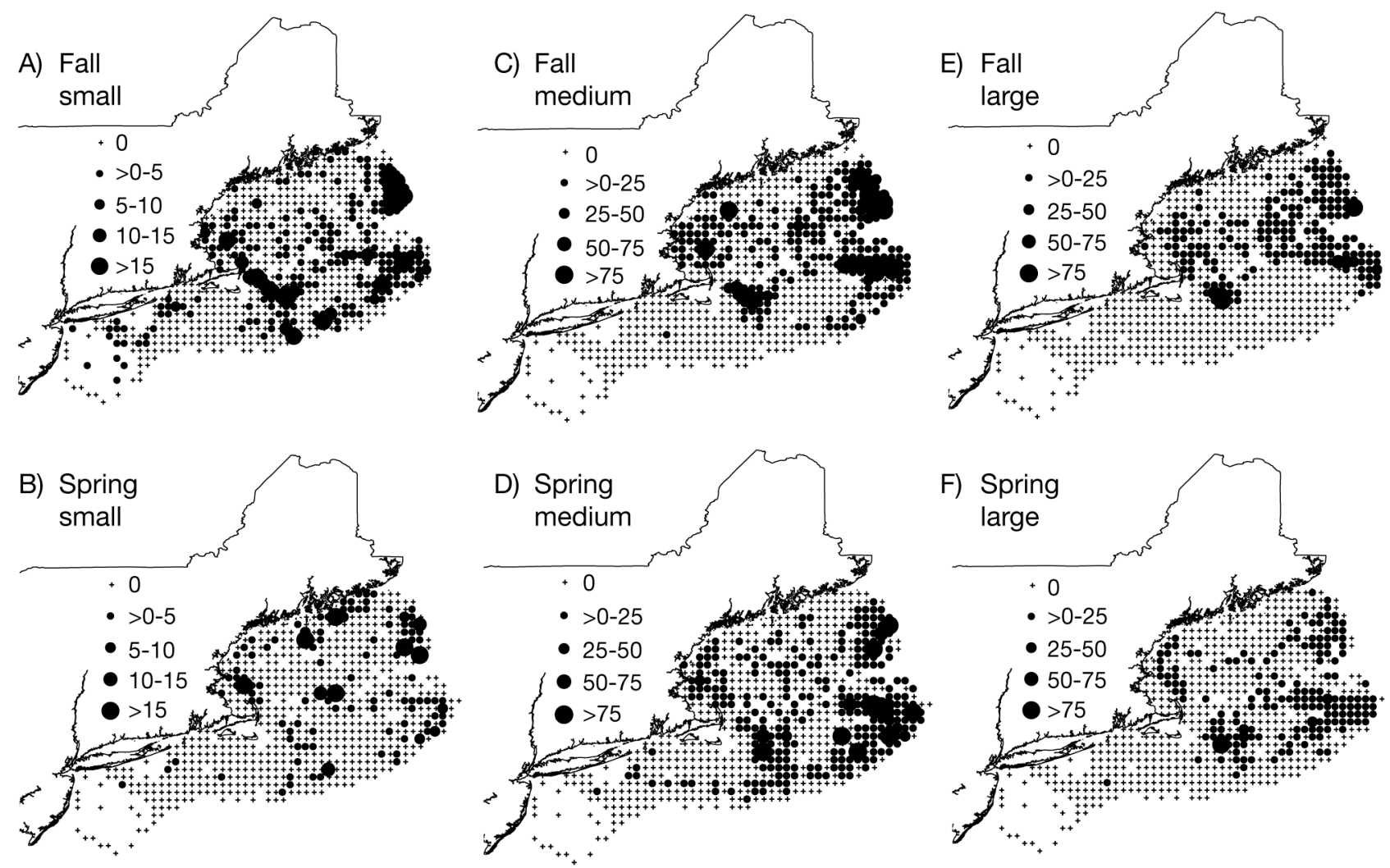

Fig. 5. Melanogrammus aeglefinus. Spatial distribution of $(A, B)$ small $(C, D)$ medium and $(E, F)$ large haddock in Gulf of Maine Georges Bank region for fall and spring for an example time-block (1990-2002)

associated with coarser substrate grain types (Fig. 4). Fish size declined over the time period in response to exploitation during both seasons, although the amount of variance explained by time-block increased 3-fold during the spring (Table 2).

\section{Spiny dogfish Squalus acanthias}

Fish size primarily decreased with depth during the fall and decreased with temperature during the spring (Fig. 6). These patterns were indicative of the temperature sensitivity and inshore-offshore migration of this species (Fig. 6). Spiny dogfish associate with the relatively warm bottom temperatures that occur in shallow depths in the fall and in deeper depths in the spring. During the spring, parturition occurs, resulting in greater overlap in the portion of the depth range occupied by juvenile and adult sizes in the spring, reducing the overall relative importance of depth (Table 2; McMillan \& Morse 1999). Accordingly, bottom temperatures had much more explanatory value during the spring.

These results are consistent with the spatial distribution of spiny dogfish. The 1-50 cm group was abundant in warmer water during the spring particularly around the southern flank of Georges Bank (Figs. 6B \&
7). Individuals $>50 \mathrm{~cm}$ in length occupied cooler water overall in the spring due to their broader distribution (Fig. 7). Individuals classified as large and extra-large (Table 2) were present throughout the region but were most abundant in shallow, gravelly areas around Cape Cod, a pattern that contributed to the notable amount of variance accounted for by substrate in the fall (Fig. 7G,H, Table 2). In contrast, during the fall, small individuals were most abundant on Georges Bank and in southern New England (Fig. 7). Intermediate-sized individuals were present throughout the region but were most abundant in the deeper waters of the Gulf of Maine and portions of Georges Bank (Fig. 7).

Time-block accounted for more variance than any environmental factor in the fall and ranked second after temperature in the spring (Table 2). Individuals from the 91-120 cm size class declined in relative abundance during the fall while the 41-120 cm group declined in the spring (Fig. 6).

\section{Silver hake Merluccius bilinearis}

Depth and temperature were more important environmental determinants of size class distribution for silver hake in the fall, while temperature was relatively more 

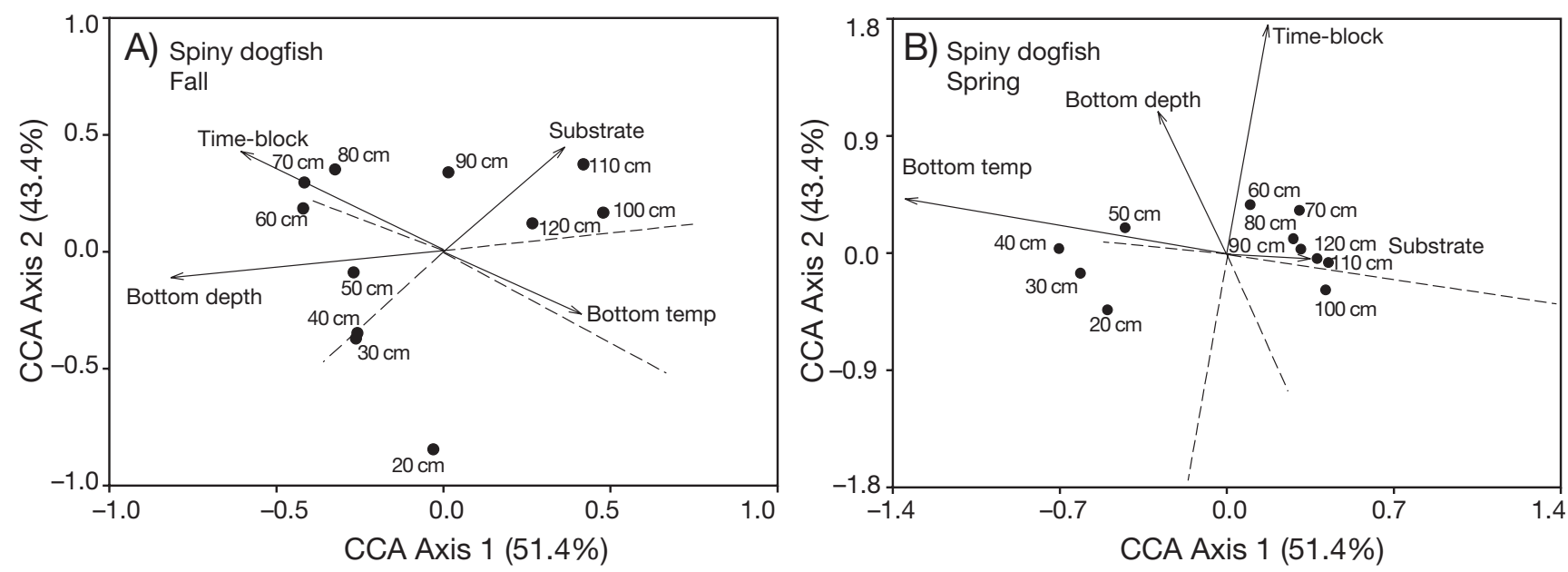

Fig. 6. Squalus acanthias. CCA ordinations for spiny dogfish size classes during (A) fall and (B) spring. CCA Axis 1 was significant in both seasons (fall, $F=60.211, p<0.01$; spring, $F=209.329, p<0.01$ ). Depth and time-block were most strongly correlated with CCA Axis 1 in the fall. During spring, bottom temperature was the factor most strongly associated with CCA Axis 1. Size class labels represent maximum length in each $10 \mathrm{~cm}$ size class

important during the spring (Table 2, Fig. 8). Although silver hake is a broadly distributed species, there were some areas where abundance was notably high. In the fall, individuals of the smallest size class $(1-10 \mathrm{~cm})$ were associated with the warmest, shallowest portions of the region on Georges Bank, southern New England, and coastal northern New England while larger size classes were concentrated in cooler, deeper water (Figs. 8 \& 9). In the spring, size primarily increased with temperature and to a lesser extent with depth (Table 2, Fig. 8B) reflecting ontogenetic movements into deeper, warmer waters. Smaller individuals were abundant in the coolest part of the region in the shallower portions of the Gulf of Maine, Southern New England, and portions of Georges Bank (Fig. 9A,B). Individuals $>10 \mathrm{~cm}$ in length were most abundant in warmer, deeper water near the southern flank of Georges Bank and portions of the Gulf of Maine (Figs. 8B \& 9).

Silver hake, like spiny dogfish, is a particularly temperature-sensitive species (Brodziak 2001, available at www.nefsc.noaa.gov/sos/spsyn/pg/silverhake/ archives). In the spring, relatively smaller individuals were associated with cooler bottom temperatures and the settlement size class $(1-10 \mathrm{~cm})$ was associated with the coolest, shallowest portion of the region, in a pattern similar to that for haddock.

Aside from the environmental variables, time-block accounted for a large proportion of variance during both seasons and was the most important factor in the fall (Table 2, Fig. 8). This is attributable to greater numbers of $1-35 \mathrm{~cm}$ individuals in the fall and 11$25 \mathrm{~cm}$ individuals in the spring as well as fewer individuals in larger categories during both seasons over the time series.

\section{DISCUSSION}

Changes that occur throughout ontogeny can generate differences within populations that are as vast as those between populations (Werner \& Gilliam 1984). The freshwater ecological literature is replete with examples of shifts in habitat associations that accompany ontogenetic shifts in physiology, resource use and the strength of interspecific and intraspecific interactions (see Werner \& Gilliam 1984 for review). Studies in marine systems that have examined size-specific or age-specific habitat associations have usually focused on 1 environmental factor, and have been conducted at relatively local scales (i.e. within a bay, coastal zone, small area of the shelf etc.) or both (e.g. Swain 1993, Linehan et al. 2001). However, in large marine ecosystems where bathymetric gradients often span 3 or more orders of magnitude and cover a wide range of thermal and benthic habitats, associations with multiple aspects of habitat are difficult to demonstrate and even more challenging to explain mechanistically (e.g. Overholtz \& Tyler 1985, Macpherson \& Duarte 1991).

We found that size increased with depth for cod, haddock and silver hake during one or both seasons. This pattern is consistent with Heincke's Law (Heincke 1913, Cushing 1975) and is evident across marine ecosystems and taxonomic groups (MacPherson \& Duarte 1991). Size-depth patterns derive from differential movement patterns of adults and juveniles during ontogeny (Cushing 1975). This may occur if individuals migrate offshore away from nursery grounds during ontogeny or if newly hatched, metamorphosed individuals migrate inshore (Cushing 1975). Distributional shifts along a depth gradient may also be 


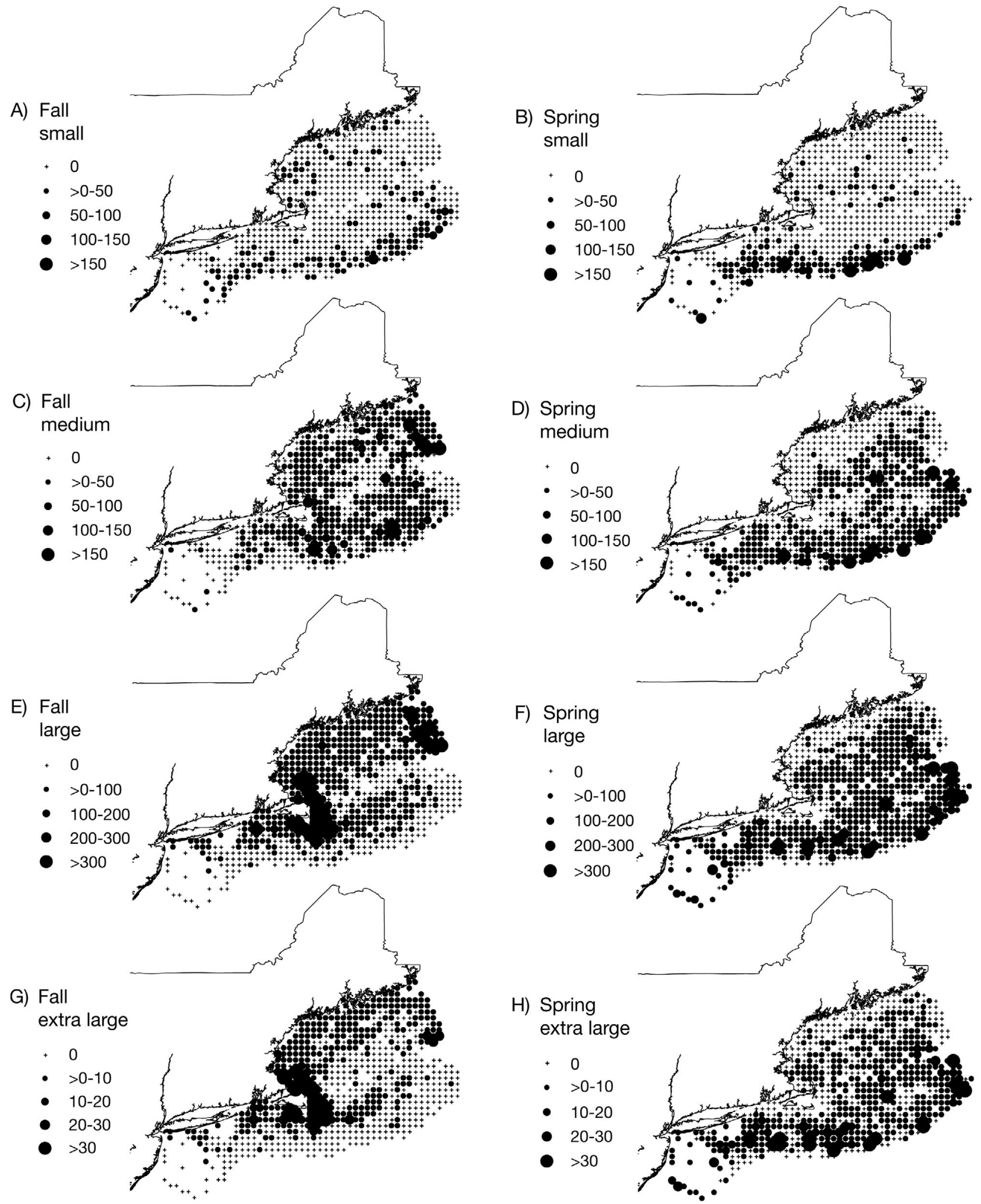

Fig. 7. Squalus acanthias. Spatial distribution of $(A, B)$ small $(C, D)$ medium $(E, F)$ large and $(G, H)$ extra-large spiny dogfish in Gulf of Maine Georges Bank region for fall and spring for an example time-block (1990-2002) 

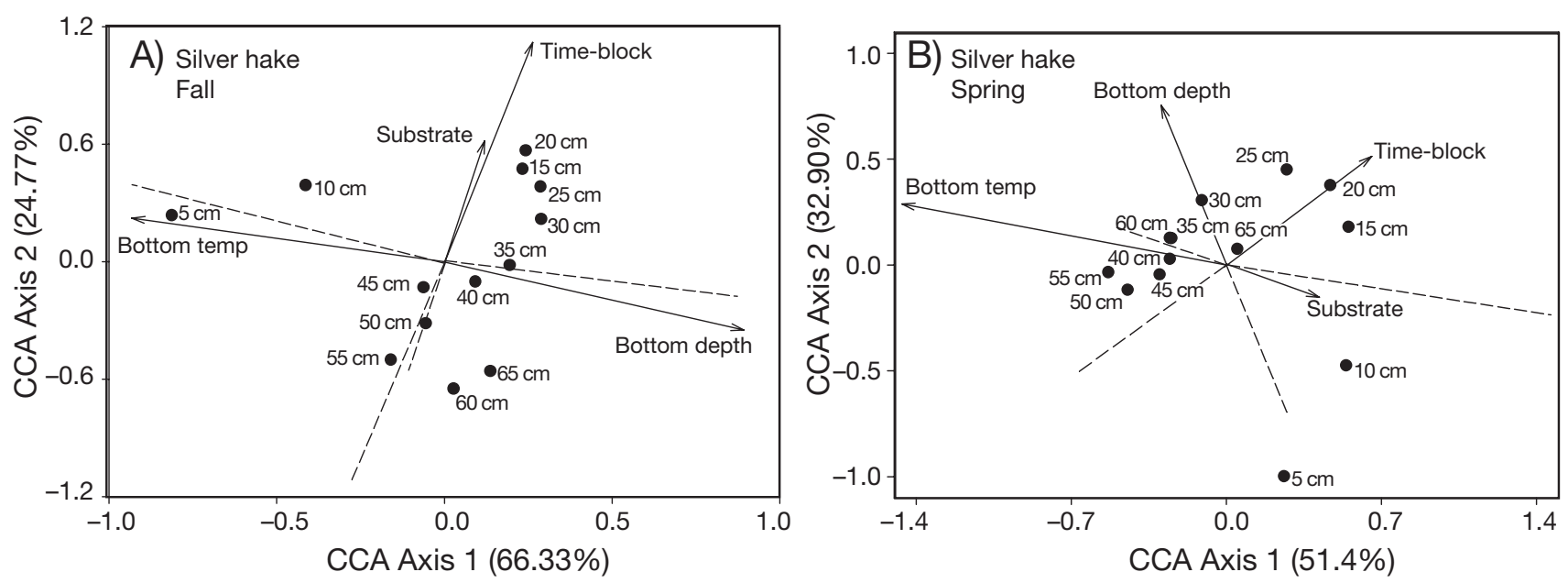

Fig. 8. Merluccius bilinearis. CCA ordinations for silver hake size classes during (A) fall and (B) spring. CCA Axis 1 was significant in both seasons (fall, $F=227.856, \mathrm{p}<0.01$; spring, $F=151.289, \mathrm{p}<0.01$ ). Depth and temperature were both highly correlated with CCA Axis 1 in fall. Temperature was most strongly correlated with CCA Axis 1 during spring. Size class labels represent maximum length in each $5 \mathrm{~cm}$ size class

affected by population density. For example, Swain (1993) showed that cod shifted their distribution with respect to depth when abundance was high, with larger fish becoming more abundant at deeper depths. In addition, we found that settlement-size individuals of cod and silver hake tended to have much different environmental associations compared to larger conspecifics especially during the spring. This indicates that settlement-size fish only survive in particular locations under particular conditions compared to larval,
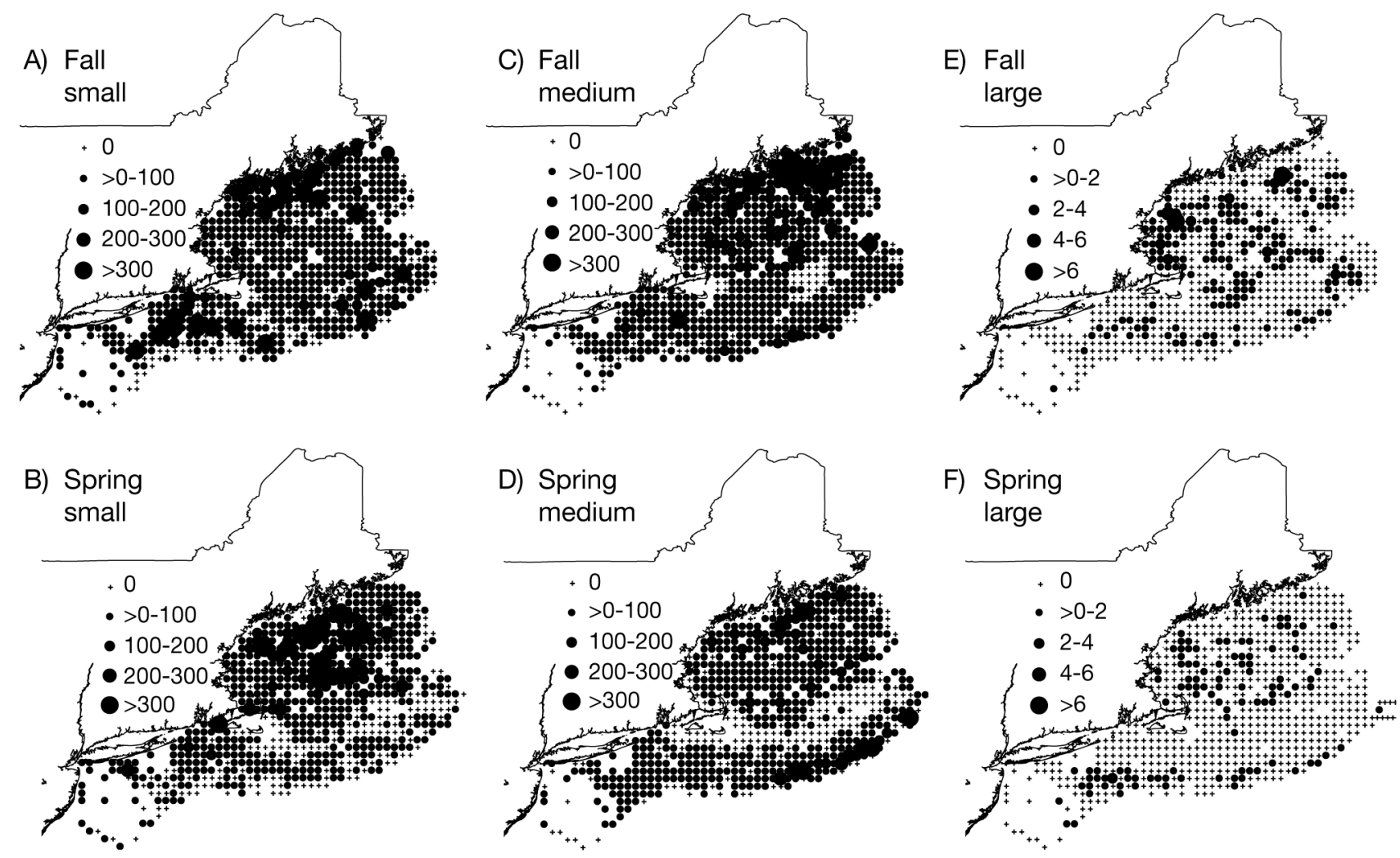

Fig. 9. Merluccius bilinearis. Spatial distribution of $(\mathrm{A}, \mathrm{B})$ small $(\mathrm{C}, \mathrm{D})$ medium and $(\mathrm{E}, \mathrm{F})$ large silver hake in the Gulf of Maine Georges Bank region for fall and spring for an example time-block (1990-2002) 
juvenile and adult stages which are often broadly distributed (Sullivan et al. 2000). For spiny dogfish, size generally decreased with depth. This species is ovoviviparous, occupying inshore waters during the fall and then moving offshore during the spring for reproduction (McMillan \& Morse 1999). The following fall, adult dogfish return to inshore waters while smaller juveniles remain in deeper areas (McMillan \& Morse 1999). Although such migrational patterns are known for many groundfish species, the factors that directly compel these movements are not well resolved (Macpherson \& Duarte 1991).

We also found that size generally decreased with increasing temperature for all species in one or both seasons. This is consistent with life history energy allocation theory which suggests that smaller individuals tend to occupy warmer waters to maximize growth rates (e.g. Fry 1971). This may be particularly advantageous when larval and juvenile stages are exposed to intense predation pressure (e.g. Linehan et al. 2001). Conversely, larger fish tend to occupy cooler waters where metabolic costs are lower and longevity is greater (Macpherson \& Duarte 1991). The importance of temperature in delimiting distributions spurred the development of the thermal niche concept (Magnuson et al. 1979), along with the recognition that distributional shifts along temperature gradients can be affected by population density (e.g. Swain 1999).

Strong associations with bottom temperature were particularly notable during the spring for all 4 species, representing a seasonal change in the relative importance of explanatory factors. Even for cod, for which depth remained the most important factor in both seasons, the explanatory value of bottom temperature more than doubled in the spring. The spring season brings with it an overall reduction in bottom water temperature across the depth gradient (Fig. 1C,D), which coincides with the reproductive season for the 4 species examined here. Of these, spiny dogfish and silver hake are probably the most cued in to temperature (Murawski \& Finn 1988, McMillan \& Morse 1999, Collette \& Klein-MacPhee 2002) and accordingly, temperature had the greatest explanatory value for these 2 species. Perhaps overall cooler bottom temperatures drive a greater sensitivity to thermal gradients in the spring (Fig. 1C,D). This seasonal differential in bottom temperature may also affect cod and haddock size class distributions; however, the temperature relationships for these 2 species are probably also entangled with depth. During the spring, the latter was nearly as important as temperature for haddock and twice as important as temperature for cod. Causal explanations for the seasonal fluctuations in relative ranking of these factors merit further investigation.
For groundfish, the ability to respond actively to changing environmental conditions varies with life history stage. The pelagic nature of early life stage gadids enables water currents and circulation patterns to retain their eggs and larvae in or near shallow spring spawning areas (Cargnelli et al. 1999). These oceanographic influences may enhance survival and may contribute to strong year-classes (e.g. Smith \& Morse 1985). Conversely, spiny dogfish have an ovoviviparous life cycle and following parturition in the winter, new pups move readily throughout their environment (Soldat 1979, Collettee \& Klein-MacPhee 2002). As individuals of each of these 4 species grow and begin actively navigating their environment, factors that scale with body size may elicit active responses that vary throughout life history.

Movement and migration patterns of demersal life stages are often spurred by seasonal fluctuations in water temperatures (Collette \& Klein-MacPhee 2002) particularly for temperature sensitive species like spiny dogfish and silver hake (Murawski \& Finn 1988, McMillan \& Morse 1999). Silver hake migrate toward warm shallow water in the spring and summer to spawn and then subsequently move to deeper water in the fall (Collette \& Klein-MacPhee 2002). The inshore waters occupied by adult spiny dogfish in the fall and the offshore waters they associate with in the spring are both relatively warm. Smaller juvenile dogfish, however, remain in the cooler, deeper areas in the fall (McMillan \& Morse 1999). Previous work in the Bay of Fundy and Scotian Shelf uncovered similar size-depth relationships for spiny dogfish but no relationship with size and temperature (Shepherd et al. 2002). By comparison, cod and haddock are less migratory, but do undergo spawning migrations and minor inshore-offshore seasonal movements to moderate their temperature (Murawski \& Finn 1988, Cargnelli et al. 1999).

Although there are clear physiological and potential fitness consequences of associating with a particular thermal or depth range, there are also numerous factors that correlate with depth and temperature and that may influence size-depth and size-temperature relationships. Predation, competition (Cushing 1975), ontogenetic shifts in feeding habits (Garrison \& Link 2000 ), or some combination of these factors may be important.

Predator-prey dynamics influence ontogenetic variation in spatial patterns for some species (e.g. Linehan et al. 2001, Gibson et al. 2002). Juvenile groundfish may be particularly vulnerable to predation due to their small size (Gibson et al. 2002). Shallow habitats provide a refuge for small juveniles hiding from predators that have a deeper water distribution, thus generating a positive size-depth relationship over shallow depth gradients (e.g. Linehan et al. 2001). Similar pat- 
terns have been demonstrated for juvenile flatfish in coastal and estuarine nursery grounds (Gibson et al. 2002). Although predation effects on size-depth patterns have not been demonstrated empirically at broad scales, they may play an important role (Macpherson \& Duarte 1991).

Ontogenetic shifts in feeding habits are common in marine ecosystems (Garrison \& Link 2000) and may influence the distribution of size classes. Both cod and haddock consume copepods and other zooplankton during larval and small juvenile stages, and then shift to benthic invertebrates upon entering the demersal phase of their life cycle (e.g. Collette \& KleinMacPhee 2000). Additionally, the degree of piscivory increases with size for cod, silver hake, and spiny dogfish (Garrison \& Link 2000). Despite the diet shifts displayed by cod, haddock and silver hake, the type of prey consumed is generally thought to be constrained mainly by predator size and is based strongly on prey availability for these species (Link \& Garrison 2002). Spiny dogfish is also considered to be an omnivorous, opportunistic predator with a diet that generally reflects prey availability (Link et al. 2002). Given the feeding behavior of these species, it is likely that distribution has a stronger effect on diet than diet has on distribution (e.g. Garrison \& Link 2000).

Competition for prey resources plays an important role in structuring some fish assemblages and could be a potential driver of size class distributions (e.g. Werner \& Gilliam 1984). The spatial segregation of size classes along a depth or temperature gradient may serve to minimize competition within species. Evidence for this exists for some species over relatively shallow depth gradients (Gibson et al. 2002). However, if $>1$ species exhibits similar size-depth patterns, then interspecific interactions may be intensified between individuals of comparable sizes whose diets and spatial distributions overlap (e.g. Kane 1984). In the Gulf of Maine - Georges Bank region, the food web is highly connected and a high degree of spatial and dietary overlap exists among many key species (Garrison 2000), suggesting the potential for significant competitive interactions. Small size classes of groundfish in particular have significant dietary overlap (Kane 1984). However, the spatial segregation of trophic guilds in this system likely reduces the importance of exploitative competition within and between species (Garrison 2000). The degree to which the avoidance of competitive interactions maintains this pattern is not well understood. Thus, although competition may influence the distribution of size classes at broad scales, the interaction strengths and relative importance of competition requires further study.
Intraspecific and interspecific interactions are often mediated by habitat type, yet the high mobility and low site fidelity of temperate marine fish make it difficult to relate these species to benthic habitats at broad scales. For example, population density can influence habitat use and further complicate our ability to link species to habitats (e.g. Laurel et al. 2004). Substrate type may influence juvenile survivorship for cod, haddock, and silver hake at local spatial scales and is one of the key factors used to designate nursery grounds for demersal fish in general (e.g. Lindholm et al. 1999). We found smaller cod and haddock to be more closely associated with coarser substrate types. However, at the large spatial scale considered, this pattern was influenced by the relationship between depth and substrate type, i.e. coarse substrates are more common in the shallow spawning areas where smaller individuals occur. Additionally, spiny dogfish and silver hake also had weak associations with this aspect of habitat. Habitat relationships have typically been difficult to detect at broader spatial scales (Overholtz \& Tyler 1985, Methratta \& Link 2006). Increased knowledge of habitat distributions and an integration of this information across multiple spatial scales will advance our ability to understand species-habitat relationships.

The effects of exploitation are reflected by the change in size class abundance over the time period for each species. Although evident in all 4 species, this effect was particularly strong for spiny dogfish during the fall season. The directed fishery that developed for spiny dogfish following the declines of other Northwest Atlantic groundfish species (Link \& Brodziak 2002) and which targeted large adults, particularly females (McMillan \& Morse 1999), likely explains the decreased abundance we observed for individuals in the largest size classes and the relative increase in intermediate sized individuals. Temporal effects were similarly important for silver hake, which may also be a result of exploitation effects (Garrison \& Link 2000) on mean fish size. Time-block accounted for relatively little variance for the more traditional target species of cod and haddock, probably because larger size classes of these species had already experienced significant mortality due to fishing (Link \& Brodziak 2002).

Understanding ontogenetic changes in habitat associations will contribute to the development of spatial approaches for fisheries management and to refinements of essential fish habitat designations (Fluharty 1999). Despite the demonstrated relationships with environmental gradients across ontogeny, there remains a considerable amount of further exploration necessary to fully determine the factors influencing these relationships. 
Acknowledgements. We acknowledge all those at the NEFSC who contributed to the planning and execution of the bottom trawl surveys. We thank the NEFSC staff for their dedicated work in auditing and maintaining the bottom trawl survey database. We also thank Michael Fahay, Kathy Lang and 3 anonymous reviewers who provided valuable comments that improved this manuscript. This work was supported in part by a postdoctoral research associateship awarded by the National Research Council (USA) to E.T.M.

\section{LITERATURE CITED}

Azarovitz T (1981) A brief historical review of the Woods Hole Laboratory trawl survey time series. In: Doubleday WG, Rivard, D (eds) Bottom trawl surveys. Can Spec Publ Fish Aquat Sci 58:62-67

Birks HJB, Peglar SM, Austin HA (1996) An annotated bibliography of canonical correspondence analysis and related constrained ordination methods (1986-1993). Abstr Bot 20: $17-36$

Cargnelli L, Griesbach SJ, Berrien PL, Morse WW, Johnson DL (1999) Haddock, Melanogrammus aeglefinus, life history and habitat characteristics. Essential fish habitat source document. NOAA Tech Memo NMFS-NE-128:1-40

Collette B, Klein-MacPhee G (eds) (2002) Bigelow and Schroeder's Fishes of the Gulf of Maine, 3rd edn. Smithsonian Institution Press, Washington, DC

Cushing DH (1975) Marine ecology and fisheries. Cambridge University Press, Cambridge

Drinkwater KF, Mountain DG (1997) Climate and oceanography. In: Boreman, J, Nakashima, BS, Wilson, JA, Kendall, RL (eds) Northwest Atlantic Groundfish: Perspectives on a fishery collapse. American Fisheries Society, Bethesda, MD, p 3-25

Fluharty D (1999) Habitat protection, ecological issues, and implementation of the Sustainable Fisheries Act. Ecol Appl 10:325-337

Fry F (1971) The effect of environmental factors on the physiology of fish. Fish physiology. VI. Academic Press, New York, p 1-98

Garrison LP (2000) Spatial and dietary overlap in the Georges Bank groundfish community. Can J Fish Aquat Sci 57: 1679-1691

Garrison LP, Link JS (2000) Diets of five hake species in the northeast United States continental shelf ecosystem. Mar Ecol Prog Ser 204:243-255

Gibson RN, Robb L, Wennhage H, Burrows MT (2002) Ontogenetic changes in depth distribution of juvenile flatfishes in relation to predation risk and temperature on a shallowwater nursery ground. Mar Ecol Prog Ser 229:233-244

Heincke F (1913) Untersuchungen über die Scholle, Generalbericht I., Schollenfischerei und Schonmaßregeln. Vorläufige kurze Übersicht über die wichtigsten Ergebnisse des Berichts. Rapp PV Cons Int Explor Mer 16:1-70

Kane J (1984) The feeding habits of co-occurring cod and haddock larvae from Georges Bank. Mar Ecol Prog Ser 16: 9-20

Laurel BJ, Gregory RS, Brown JA, Hancock JK, Schneider DC (2004) Behavioral consequences of density-dependent habitat use in juvenile cod Gadus morhua and G. ogac: the role of movement and aggregation. Mar Ecol Prog Ser 272: 257-270

Lindholm JB, Auster PJ, Kaufman LS (1999) Habitat-mediated survivorship of juvenile (0-year) Atlantic cod Gadus morhua. Mar Ecol Prog Ser 180:247-255

Linehan JE, Gregory RS, Schneider DC (2001) Predation risk of age- 0 cod relative to depth and substrate in coastal waters. J Exp Mar Biol Ecol 263:25-44

Link J, Brodziak J (2002) Report on the status of the NE US Continental Shelf Ecosystem. NEFSC Ecosystem Status Working Group. Northeast Fisheries Science Center Ref Doc 02-11

Link JS, Garrison LP (2002) Trophic ecology of Atlantic cod Gadus morhua on the northeast US continental shelf. Mar Ecol Prog Ser 227:109-123

Link JS, Garrison LP, Almeida FP (2002) Interactions between elasmobranchs and groundfish species (Gadidae and Pleuronectidae) on the Northeast U.S. Shelf. I: Evaluating predation. N Am J Fish Manage 22:550-562

Macpherson E, Duarte CM (1991) Bathymetric trends in demersal fish size: is there a general relationship? Mar Ecol Prog Ser 71:103-112

Magnuson JJ, Crowder LB, Medvick PA (1979) Temperature as an ecological resource. Am Zool 19:331-343

McCauley R, Read LAA (1973) Temperature selection by juvenile and adult yellow perch (Perca flavescens) acclimated to 24C. J Fish Res Board Can 30:1253-1255

McMillan DG, Morse WW (1999) Spiny dogfish, Squalus acanthias, life history and habitat characteristics. Essential fish habitat source document. NOAA Tech Memo NMFS-NE-150:1-28

Methratta ET, Link JS (2006) Associations between surficial sediments and groundfish distributions in the Gulf of Maine - Georges Bank region. N Am J Fish Manage 26: 473-489

Murawski SA, Finn JT (1988) Biological basis for mixed-species fisheries: species codistribution in relation to environmental and biotic variables. Can J Fish Aquat Sci 45: 1720-1735

Overholtz WJ, Tyler AV (1985) Longterm responses of the demersal fish assemblages of Georges Bank. Fish Bull US 83: 507-520

Poppe LJ, Paskevich VF, Williams SJ, Hastings ME and 5 others (2003) Surficial sediment data from the Gulf of Maine, Georges Bank, and vicinity: a GIS compilation. US Geological Survey Open-File Report 03-001

Shepherd T, Page F, Macdonald B (2002) Length and sexspecific associations between spiny dogfish (Squalus acanthias) and hydrographic variables in the Bay of Fundy and Scotian Shelf. Fish Oceanogr 11:78-89

Smith WG, Morse WW (1985) Retention of larval haddock, Melanogrammus aeglefinus, in the Georges Bank region, gyre-influenced spawning area. Mar Ecol Prog Ser 24: $1-13$

Soldat VT (1979) Biology, distribution, and abundance of the spiny dogfish in the northwest Atlantic. Int Comm Northwest Atl Fish (ICNAF) Res Doc 79/VI/102

Sullivan MC, Cowen RK, Able KW, Fahay MP (2000). Spatial scaling of recruitment in four continental shelf fishes. Mar Ecol Progr Ser 207, 141-154

Swain D (1993) Age- and density-dependent bathymetric pattern of Atlantic cod (Gadus morhua) in the southern Gulf of Saint Lawrence. Can J Fish Aquat Sci 50:1255-1264

Swain DP (1999) Changes in the distribution of Atlantic cod (Gadus morhua) in the southern Gulf of St. Lawrenceeffects of environmental change or change in environmental preferences. Fish Oceanogr 8:1-17

ter Braak CJF (1986) Canonical correspondence analysis: a new eigenvector method for multivariate direct gradient analysis. Ecology 67:1167-1179

Wentworth CK (1922) A scale of grade and class terms for clastic sediments. J Geol 30:377-392

Werner E, Gilliam JF (1984) The ontogenetic niche and species interactions in size-structured populations. Annu Rev Ecol Syst 15:393-425

Submitted: July 15, 2005; Accepted: October 2, 2006

Proofs received from author(s): May 10, 2007 